\title{
Real Time PCR
}

National Cancer Institute

\section{Source}

National Cancer Institute. Real Time PCR. NCI Thesaurus. Code C51962.

An application of PCR that measures the products generated during each cycle of the polymerase chain reaction process in order to determine the starting amount of template in the reaction. 